Méditerranée (LIESM). Monaco, Impr. Nat. (1964) 1005-1007).

Quakernaat, J., 1968. X-ray analyses of clay minerals in some recent fluviatile sediments along the coasts of central Italy. (Amsterdam, Fisisch-Geografisch lab. Van de Univ., No. 12).

Rathnam, K. V., and Ryan, W. B. F., 1969. Dispersal patterns of clay minerals in the sediments of the Eastern Mediterranean. Amer. Geophys. Union Trans. 50, 198.

Rateev, M. A., Emelianov, E. M., and Kheirow, M. B., 1966. Contribution for the formation of clay minerals in contemporaneous sediments of the Mediterranean sea. (Litol. i polez. iskopaemi., No. 4, 6, Akad, Nauk. SSSR.).
Sukhri, N. M., 1950. The mineralogy of some Nile sediments. (Quat. J. Geol. Soc. Lond. 105, 513, 106, 466.)

Tomadin, L., 1970. Minéraux argileux de vases tyrrhéniennes. (22e Congr. Com. Int. Etud. Sc. Méditerranée (CIESM). Rome 1970, résum's des communications).

von der Borch, C. C., Nesteroff, W. D., and Galehouse, J., 1971. Iron rich sediments cored during Leg 8 of the Deep sea drilling project. In Tracey J. I., Jr. et al, 1971, Initial Reports of the Deep Sea Drilling Project, Volume VIII. Washington (U.S. Government Printing Office). 829.

\title{
20.3. A PRELIMINARY INVESTIGATION OF THE CLAY MINERALS IN THE WESTERN ALBORAN BASIN, SITE 121
}

\author{
G. Dunoyer de Segonzac, and M. Hoffert, Institut de Géologie, Université de Strasbourg, France.
}

\section{INTRODUCTION}

Site 121 of the Deep Sea Drilling Project is located above the floor of the Western Alboran Basin of the Mediterranean Sea, a few kilometers north of the central flat-floored plain, at a water depth of 1163 meters. The drill hole penetrated sediments of Pleistocene, Pliocene, and late Miocene age and terminated at 868 meters below bottom in a basement of quartz-biotite schist and granodiorite. Twenty-four cores were taken, and from the recovered sequence 28 samples were analyzed for the present study.

The small size $(\approx 5$ grams $)$ of the shipboard samples precluded determination of the mineral assemblages other than those of the fine silicate fraction $(<2 \mu)$.

The distribution of clay minerals in the sequence penetrated is remarkably homogeneous (Figure 1). However, a careful examination of the individual diffractograms and of computations of the abundances and relative proportions of the various clay minerals does allow a subdivision of the clay variations into two types.

\section{Techniques}

The greater-than-63- $\mu$ sand fraction of each sample was removed by sieving, and the carbonate material was destroyed by treating with $0.1 \mathrm{~N} \mathrm{HCl}$. The less-than- $2-\mu$ clay fraction was separated first by decanting and then with a centrifuge. After $\mathrm{Mg}^{++}$saturation, the sediment was smeared as a mud slurry onto a glass slide. The X-ray diffraction patterns were obtained with a Phillips instrument and were presented graphically on a Hewlett-Packard X-Y Plotter.

\section{DIAGENETIC ALTERATION IN RELATION TO THE DEPTH OF BURIAL}

\section{Formation of Montmorillonite}

The montmorillonite becomes more abundant relative to illite $(18 \AA / 10 \AA$ ratio in Figure 1) toward the bottom of the drillhole. Furthermore, the illite shows no qualitative systematic variation in the samples analyzed (as indicated in the width of the $10 \AA$ peak at its $1 / 2$ peak height and by the comparison of the intensity of the $5 \AA$ and $10 \AA$ peaks).

In contrast, there is a sympathetic relationship between the relative increase in the abundance of montmorillonite down hole and a simultaneous perfection in its crystallinity. This observation is deduced from the parameters developed by Chamley (1971) and Biscaye (1965) concerning the geometry of the $17 \AA$ peak after glycolization, and is particularly evident in the interval between 520 and 860 meters below bottom.

A preliminary interpretation of the diffractograms suggests that the clay assemblage contained a three layered mineral composed of illite, interstratified illite-montmorillonite, and montmorillonite, which after hydration, has evolved into montmorillonite. This original component, known as the "complexe gonflant" after Chamley (1971), is reorganized to montmorillonite with two interlayers of water. Such a re-ordering occurs in an endothermic reaction aided by the increase in temperature and burial depth. If this interpretation can be confirmed, it will provide insight into the diagenetic evolution of clays upon burial after deposition. Up to the present time, we have only observed the dehydration of montmorillonite under the effect of increased lithostatic pressure (first stage of Burst, (1969) 
between 700 and 2500 meters; Dunoyer, (1969) primarily because of a lack of deep cores from recent sedimentary strata.

\section{Aggradation of the Chlorites}

The relative abundance of chlorite is quite constant through the sequence cored; however, its crystallinity improves markedly with depth as evidenced by the $4.7 \AA$ peaks. One can see in Figure 1, from the ratio of the $4.7 \AA$ chlorite peak to the $5 \AA$ illite peak, a diagenetic evolution under the influence of burial. For example, the absorption of magnesium by clay from the connate waters takes place preferentially to that of potassium up to a certain "equivalence level" (Powers, 1959). This level apparently is not reached here at the base of the sedimentary column.

\section{Stratigraphic Breaks}

The marked increase in the relative abundance of montmorillonite versus illite, and a corresponding abrupt improvement in crystallinity of the montmorillonite (V/P ratio) between Cores 15 and 18, demonstrate a significant difference in the clay mineral assemblages across the major Pliocene-upper Miocene angular unconformity at 686 meters below bottom (see Chapter 3, Part I, this Volume).

A new stratigraphic break within the Pliocene is inferred at 520 meters (Core 10) based on the marked change in the crystallinity of montmorillonite $(\alpha$ measurements and V/P ratio in Figure 1). This break apparently was not revealed in the shipboard lithologic and micropaleontological investigation of the cores. It is of great importance to confirm whether a major stratigraphic break corresponds to this mineralogical change.

A marker level was discovered at 250 meters within the Quaternary marl oozes, characterized by the presence of serpentine. Its fibrous nature is easily recognized in electron photomicrographs, and it is apparently of detrital origin. Since the period of deposition of the serpentine (found only in Core 4) might signify its first introduction into the sediment source region, it is possible that this marker horizon dates the emplacement of the well-mapped serpentinite masses in Spain and/or Morocco, thus furnishing an important chronological datum in the recent tectonic evolution of the Betic and Rif mountain belts.

\section{REFERENCES}

Biscaye, P.E., 1965. Mineralogy and sedimentation of recent deep-sea clay in the Atlantic Ocean and adjacent seas and oceans. Bull. Geol. Soc. Am. 76, 803.

Burst, J.F., 1969. Diagenesis of Gulf Coast clayey sediments and its possible relation to petroleum migration. Bull. Am. Assoc. Petrol. Geologists 53, 73.

Chamley, H., 1971. Recherches sur la sedimentation argileuse en Mediterranie. In print in Mém. Serv. Carte Géol. Alz. Lorr. Strasbourg.

Dunoyer de Segonzac, G., 1969. Les mineraux argileux dans la diagénèse. Passage au métamorphisme. Mém. Serv. Carte Géol. Alz. Lorr. Strasbourg, h'29, 320.

Powers, M. C., 1959. Adjustment of clay to chemical change and the concept of equivalence level. Clays and Clay Min. (6th Nat. Conf. 1957), 309. 


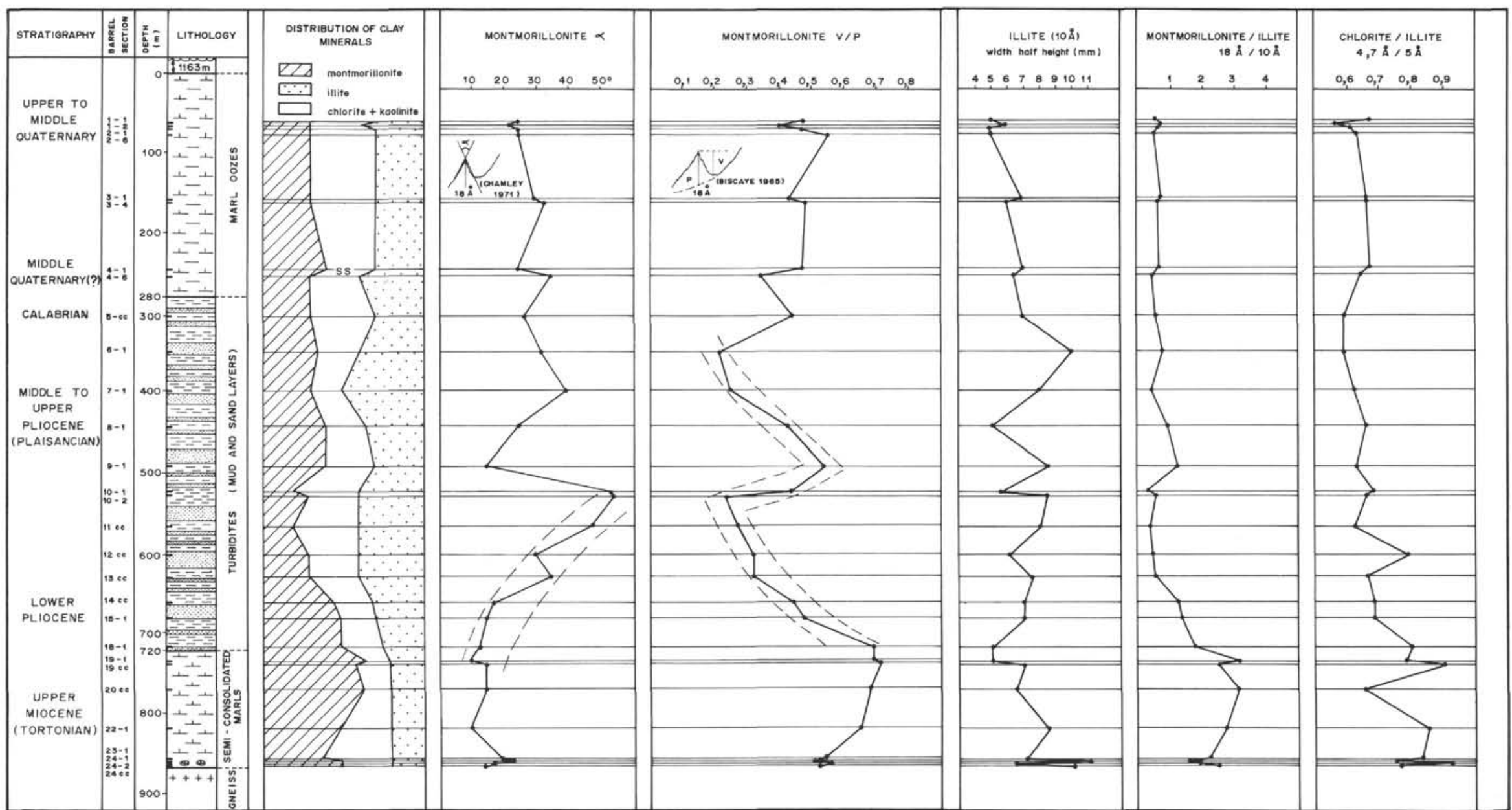

Figure 1. Relative abundance and crystallinity of the clay minerals in the western Alboran Basin (Site 121). 